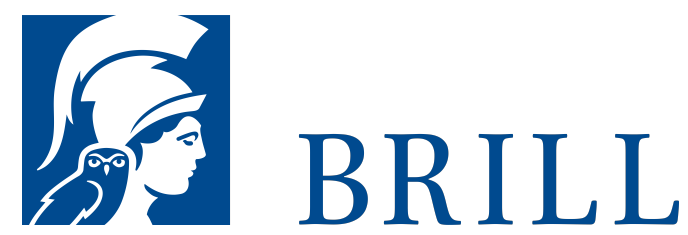

\title{
Die Körper des Königs
}

Effigies, Bildpolitik und Heiligkeit

Author: Kristin Marek

Der Historiker Ernst Kantorowicz hat, mit nachhaltiger Wirkung, die These von den 'zwei Körpern des Königs' formuliert, aufgeteilt in einen natürlichen und einen politischen Körper. Doch sind es wirklich nur zwei Körper, welche die Geschichte des christlichen Königs prägten? Im Mittelalter lassen sich, wie Kristin Marek zeigen kann, mindestens drei repräsentative Körperkonzepte bestimmen: Neben dem natürlichen und politischen existiert eine dezidierte Vorstellung vom heiligen Körper. Vor diesem Hintergrund erscheint die Effigies, das seit dem 14. Jahrhundert gebräuchliche bildliche Double des Königs im Funeralzeremoniell, in einem völlig neuen Licht. Ist dieser Bild-Körper tatsächlich Ausdruck des Heiligen im Sinne Agambens oder doch eher Ort des Politischen? Oder sind Bild und Körper des Königs nicht viel mehr Teil einer Politik, die immer wieder neu zwischen verschiedenen Bild- und Körperkonzepten unterscheidet? Präsentation des Körpers.

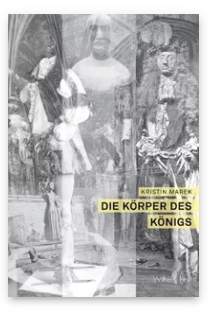

Pages: 310

Seiten, $60 \mathrm{~s} / \mathrm{w}$ Abb.

Language:

German

Subjects:

General, Art

History

Publisher: Brill |

Fink

E-Book (PDF)

Released online:

$20 \mathrm{Jan} 2 \mathrm{O} 2 \mathrm{O}$

ISBN: $978-3^{-}$

$8467-453^{2-8}$

List price

USD \$42.00

Paperback

Publication date:

18 Mar 2009

ISBN: 978-3-

7705-4532-2

List price

USD \$42.00 
For more information see brill.com

Order information: Order online at brill.com +44330 333 0049 | customerservices@brill.com Submission information: brill.com/authors

Titles published by Brill | Fink, Brill | mentis or Brill | Schöningh: +49(o)715413279216| brill@brocom.de 